\title{
Analysis of Peranakan Etawah Goat Breed Production Efficiency in North Samarinda Sub-District
}

\author{
Surya Nur Rahmatullah*, Rudi Saputro, and Muhammad Erwan Suriaatmaja
}

\author{
Animal Science Department, Agriculture faculty, Mulawarman University, Kampus Gunung Kelua Street Pasir \\ Balengkong Street PO.BOX.1040 Contact (0541) 749159, 749313, Fax. 738341 Samarinda 75123 \\ *Corresponding author. Email: suryanr@faperta.unmul.ac.id
}

\begin{abstract}
The sustainability of meat supply has to support by animal production efficiency, understanding the technical efficiency of the Peranakan Etawah goat farming is essential. The current study assessed the technical efficiency of Peranakan Etawah goat production in the North Samarinda Sub-District. A purposive sampling technique was used to select 15 respondents from the study area. The data was collected through a well-structured questionnaire. The analytical tools employed were descriptive statistics and stochastic frontier production function. The result showed that the mean age of the respondents was 44.467 years. The result of the Stochastic Frontier production function showed that the number of buckling and frequency of feed had a positive significant effect on the production output. Farming experience had a negative significant effect on the production output. The mean efficiency was 0.92 , indicating a high level of technical efficiency. The study also revealed that the farmers are faced with the problem of lack of access the supplement feed. Although the Peranakan Etawah goat farmers are technically efficient, efficiency could be increased through better use of the available resource.
\end{abstract}

\section{Keywords: Technical efficiency, Peranakan Etawa Production, North Samarinda}

\section{INTRODUCTION}

Goat meat is widely consumed and is an important source of animal protein [1]. Essential in human nutrition because of its biological significance, goat meat also plays a strategic role in alternative beef substitutions in the effort to achieve self-sufficiency in meat, and encourage increased public income [2]. One of the diversified instruments of animal food providers, the development of goat needs to be endeavored to maintain the availability, distribution, and consumption [3]. The development of domestic livestock can be pursued through increased production, and productivity [4] by producing technological innovations to improve efficiency [5].

In Indonesia, 99\% of ruminants are the hand of smallholder farmers [6]. On average, the number of keeping goats (2-8 head) [7]. The capacity of most smallholder farmers is also the low yielding quality and there is a critical knowledge gap know in the combination of production factors [5], which became one of the strategic issues of farming inefficiencies in the development of farms in general that focuses on the demonstration of systems and the rationality of farmers [8].
Management is related to technical efficiency, i.e. output per unit all inputs are aggregated in a way [9], is the principle of optimization the use of production factors as efficiently as possible [10]. Economics has given a theory about the use of efficient based production concept [9], in which the function shows the technical relationship between inputs and outputs in production [11]. Technical efficiency in the stochastic frontier approach is a relevant method that assumes the function of a product is approaching frontier condition [9]. The magnitude of the level of technical efficiency is thus measurable from the inputs provided and can be estimated whether the frontier deviation is caused by inefficiencies or other factors from outside that can not be controlled production unit [11].

Factors affecting production (with an emphasis on livestock output) are the physical environment (a breed of a goat), feed input, cultivation techniques, livestock ownership, and socioeconomic factors. The physical environment influences output, both directly and indirectly through its influence on the level and frequency of input use. There is an influence of livestock farming techniques and leadership on yields, while socioeconomic factors influence yields indirectly through their influence on farmers' decision-making in using input levels. Several studies analyzing technical efficiency in the field of animal husbandry business. The research 
includes $[12,13,14,15]$ who have applied Stochastic Frontier to measure the level of technical efficiency of chickens, goats, cattle, and pigs. Starting from the description, the study tried to analyze the level of technical efficiency of Peranakan Etawah goat production in the North Samarinda Sub-District, City of Samarinda. The objective of this study is to assess the technical efficiency of Peranakan Etawah goat farming in a fully confined condition production system in North Samarinda Sub-District by applying the stochastic frontier approach.

\section{RESEARCH METHOD AND DATA}

Cross-section data was used in the survey. A purposive sampling technique was used to select 15 respondents from the study area. The goat farmers' samples are determined by participatory rural appraisal, frame of the farm families, who were goat farmers (owning at least two bucklings between 8-12 months). The stochastic frontier production function was used to analyze the technical efficiency and its determinants in Peranakan Etawah goat production, in the study area. Descriptive statistics, such as percentages, frequencies, and tables were used to analyze data provided by the respondents. Coefficients of the estimated model were tested using t-test statistics.

For this study, the production technology of the farmers is assumed to be specified by the Cobb Douglass frontier production function defined as follows: $\ln$

$\mathrm{Y}=\ln \beta 0+\beta 1 \ln \mathrm{X} 1+\beta 2 \ln \mathrm{X} 2+\beta 3 \ln \mathrm{X} 3+\beta 4 \ln$ $\mathrm{X} 4+\mathrm{vi}-\mathrm{ui}$

Note

$\mathrm{Y}=$ buckling weight $(\mathrm{kg})$

$\mathrm{X} 1$ = number of bucks

$\mathrm{X} 2$ = frequency of feed

$\mathrm{X} 3$ = frequency of drug/vitamin

X4 = labor (manday)

$\mathrm{Vi}=$ Random error that is assumed to be normally distributed with zero mean and constant variance ( $\sigma 2$ vi)

$\mathrm{Ui}=$ Technical inefficiency effects independent of $\mathrm{Vi}$ , and half normal distribution with zero mean and constant variance $(\sigma 2$ ui)

The technical inefficiency effects, Ui is defined by: ¿5Z6i

$\mathrm{Ui}=\delta \mathrm{o}+\delta 1 \mathrm{Z1i}+\delta 2 \mathrm{Z2} \mathrm{i}+\delta 3 \mathrm{Z3} \mathrm{i}+\delta 4 Z 4 \mathrm{i}+\delta 5 \mathrm{Z5i}+$

Note

Z1 = Household size

$\mathrm{Z} 2$ = size cage per head goat $\left(\mathrm{m}^{2}\right)$

$\mathrm{Z} 3$ = dummy feed supplement $($ yes $=1$, no $=0$ )
$\mathrm{Z} 4$ = Age of farmer (years)

$\mathrm{Z5}=$ Level of education of farmer (years)

$\mathrm{Z6}=$ Farming experience (years) Goat weight is expected to be influenced positively by the number of bucks, frequency of feed, frequency of drugs/vitamins, and labor.

Apriori, dummy feed supplement, level of education, and farming experience are expected to have negative effects on the technical inefficiency while household size, size of goat cage, age of the farmer is expected to have a positive effect. The $\beta$ s and $\delta$ s are scalar parameters that will be estimated. The variances of the random errors, $\sigma 2 \mathrm{v}$ and that of the technical inefficiency effects $\sigma 2 \mathrm{u}$ and the overall variance of the model $\sigma 2$ are related thus: $\sigma 2=\sigma 2 \mathrm{v}+\sigma 2 \mathrm{u}$ and the ratio $\gamma=\sigma 2 \mathrm{u} / \sigma 2$, measures the frontier which can be attributed to technical inefficiency [13]. The estimates for all the parameters of the stochastic frontier production function and the inefficiency model would be simultaneously obtained in a single-stage maximum likelihood estimation procedure, using the computer software Frontier version 4.1.

\subsection{Variable Selection and Data Description}

According to the requirements of the stochastic frontier production function model to the input and output indicators, we selected the weight of buckling in $\mathrm{kg}$ as the output variable when calculating the technical efficiency of farmers in Peranakan Etawah goat farming. The input variables are the number of bucks, frequency of feed during the fattening period, frequency of drug/vitamin during the fattening period, and input labor (total working days of free labor during the fattening period, and converted into standard work by eight hours). In the aspect of analyzing the factors affecting the technical efficiency of Peranakan Etawah goat production, we adopted socio-economic conditions and identify the problems faced in goat production in the study area. In the present study, data on output and inputs are used to estimate farmers' level technical efficiency of Peranakan Etawah goat production. The results of the statistical analysis of the variables and the main results are shown in Table 1 .

\section{RESULT AND DISCUSSION}

\subsection{Socio-Economic Characteristics of the Respondents}

The socio-economic characteristics of the goat farmers in the study area are presented in Table 1 . The result indicates that a good number of goat farmers $(40.0 \%)$ are between $36-50$ years of age while $33.0 \%$ are more than 50 years of age and $27.0 \%$ are between $20-35$ years of age. The average age of goat farmers is 44.467 years. This shows that most of the farmers are young and 
Table 1. Percentage Distribution of the Socio-Economic Characteristics of the Respondents

\begin{tabular}{|c|c|c|}
\hline Index & Frequency & Percentage \\
\hline \multicolumn{3}{|l|}{ Age } \\
\hline $20-35$ & 4 & 27 \\
\hline $36-50$ & 6 & 40 \\
\hline$>50$ & 5 & 33 \\
\hline Total & 15 & 100 \\
\hline \multicolumn{3}{|c|}{ Farming experience } \\
\hline$<5$ & 12 & 80 \\
\hline $5-10$ & 2 & 13 \\
\hline$>10$ & 1 & 7 \\
\hline Total & 15 & 100 \\
\hline \multicolumn{3}{|c|}{ Years spent in school } \\
\hline 6 & 4 & 27 \\
\hline 9 & 7 & 46 \\
\hline 12 & 3 & 20 \\
\hline 16 & 1 & 7 \\
\hline Total & 15 & 100 \\
\hline \multicolumn{3}{|c|}{ Household size } \\
\hline $1-10$ & 8 & 54 \\
\hline $10-20$ & 5 & 33 \\
\hline$>20$ & 2 & 13 \\
\hline Total & 15 & 100 \\
\hline
\end{tabular}

agile to carry out the production activities. This result suggests that age may increase technical efficiency because young farmers who are very energetic and may have learned efficient routines and practices constitute the majority of goat farmers in the study area. From the results to the average farming experience of the goat farmers is 4.08 years. Farming experience may increase technical efficiency as experience has a positive influence on managerial ability as it tends to improve the ability of the farmers to obtain and process information about technology which in turn increases efficiency. The average number of years spent by the farmers in school as computed from the results is 9.26 years. In all $100 \%$ of the respondentsare literate farmers. The implication of this high level of literacy in the study area is that most of the goat farmers have the ability to obtain and process information about input use. This result suggests that the educational level of farmers probably increases the technical efficiency of goat farmers in the study area. The average household size of the goat farmers as computed based on the frequencies is 15.8. This large household size may translate to higher use of family labor. This implies that the cost of hiring labor is reduced.

\subsection{Estimate of Stochastic Frontier Production Parameter}

The maximum likelihood estimate of the stochastic frontier production function for Peranakan Etawah goat farmers is presented in Table 2. The low sigma-squared value $(0,011)$ in Table 2 . indicates that the error term inefficiency (ui) is normally distributed. Statistically, a gamma value of 0.985 indicates that $98.5 \%$ of variation residuals in the model come from inefficiencies in the production process (ui) and the rest $(1.5 \%)$ are caused by a random error in measurements (vi) (noise). If the $\gamma$ approach is null, interpreted that all errors' terms come from noise (vi) and the inefficient coefficient of production is not meaningful.

The log-likelihood value in the MLE method (21.256) is higher than the log-likelihood value by the OLS method (19.120), which means the MLE method is better than the OLS method to describe the situation on the ground, so the MLE method is chosen as a method for estimating frontier production functions of goat farming in North Samarinda District. Table 2. is a table that summarizes the results of estimating the stochastic function of frontier production by the MLE method. 
Table 2. Percentage Distribution of the Socio-Economic Characteristics of the Respondents

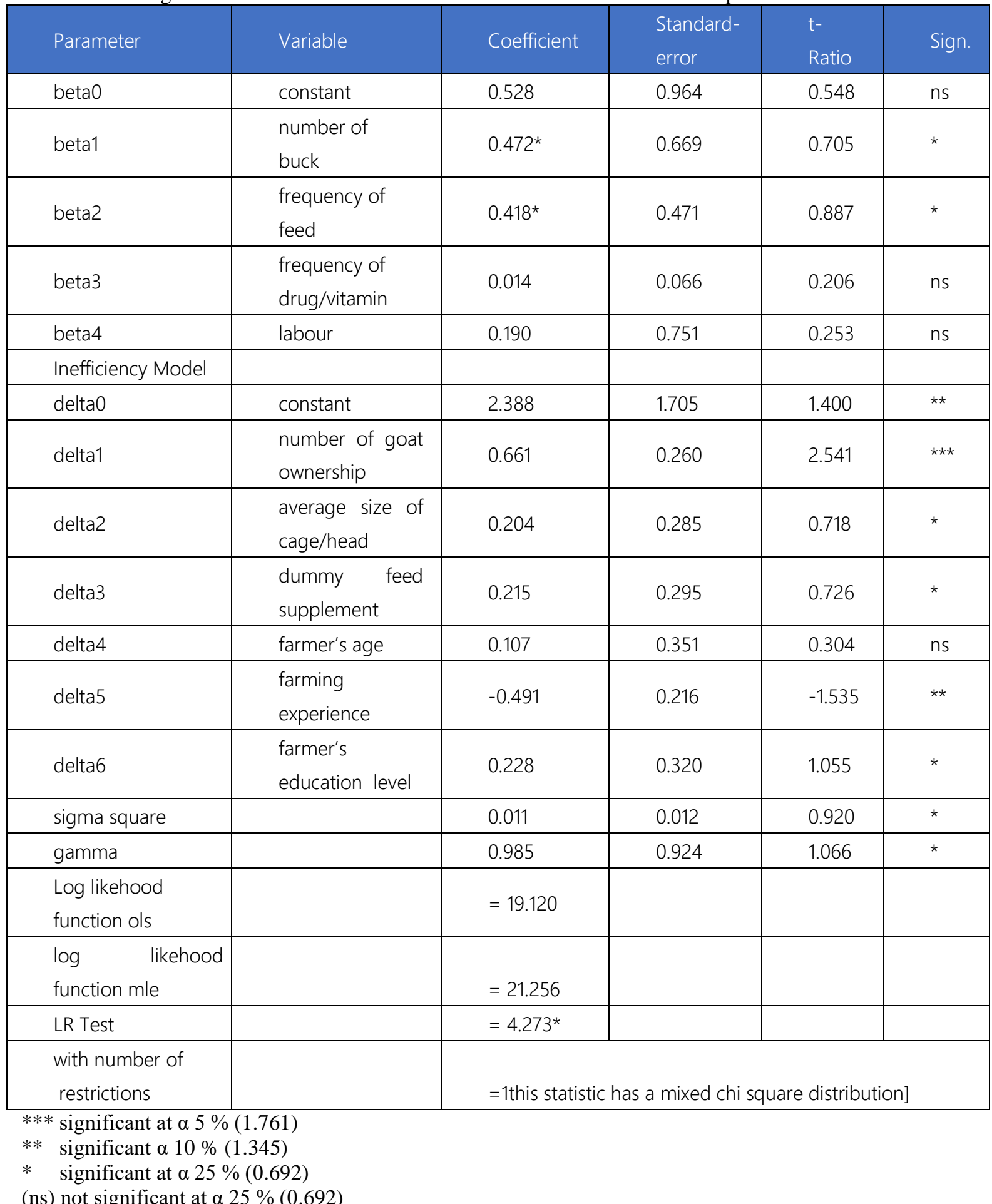

\subsection{Analysis of factors influencing Peranakan Etawah Goat production}

Stochastic Frontier Approached used to analyze factors influencing Peranakan Etawah goat production is Maximum Likelihood Estimation (MLE) approaches, following is the influence of production factors:

\subsubsection{Number of buck}

According to Table 2., it is known that the number of bucks has a positive coefficient of 0.472 with a t-count of 0.705 , in addition, the t-count value is higher than the ttable by 0.692 . This indicates that the variable has a significant influence on the Peranakan Etawah goat production with an error level of $25 \%$ or a trust level of $75 \%$. The number of bucks has a regression coefficient of 0.472 which means that each addition of $1 \%$ of a 
Table 3. Efficiency Frequency Distribution of Farmer Respondents in Peranakan Etawah Goat Production in North Samarinda Sub-District

\begin{tabular}{|l|c|c|}
\hline \multicolumn{1}{|c|}{ Efficiency level } & Frequency & Percentage \\
\hline $0.71-0.80$ & 1 & 6.67 \\
\hline $0.81-0.90$ & 4 & 33.33 \\
\hline$>0.90$ & 9 & 60 \\
\hline Total & 15 & 100 \\
\hline Mean efficiency & 0.92 & \\
\hline Minimum efficiency & 0.79 & \\
\hline Maximum efficiency & 0.99 & \\
\hline
\end{tabular}

number of bucks will be able to increase the productivity result with an additional $0.472 \%$, ceteris paribus. It makes sense, because, without a buck, there will be no production activity.

\subsubsection{Frequency offeed}

The frequency of feed has a regression coefficient of 0.418 , with a t-count of 0.887 , in addition, the t-count value is higher than the t-table by 0.692 . The value of the most large-range regression coefficient among other production factors implies that the most responsive production results in the frequency of feed. Principally the efficiency of feed use increased following the consumption level. Feed consumption increases when the frequency of feed increases. Meanwhile, Peranakan Etawah goat farmers in North Samarinda Sub-District apply the frequency of feed twice and three times a day. [14] in her research mentioned that the provision of forage for goats should be done gradually and at least four times a day overnight

\subsubsection{Frequency of drug/vitamin}

The coefficient value of frequency of drug/vitamin variable is positive by 0.014 and the t-count value is 0.206 . Therefore, the $\mathrm{t}$-count value is smaller than the $\mathrm{t}$ table at the level of $25 \%$ (0.692), as a result, the factor of frequency of drug/vitamin has a positive but not significant influence over the Peranakan Etawah goat production in the research area. This variable has a positive coefficient which means this changer has a direct relationship with production so that it can be said.

\subsubsection{Labor}

The coefficient value of the labor variable is positive by 0.190 and the $t$ count value is 0.253 . According to this matter, the t-count value is smaller than the t-table at the level of $25 \%$ (0.692), thus, the labor factor has a positive influence but is not significant to the Peranakan Etawah goat production in the research area. This indicates the more the labor used in goat farming, the more increased production resulted. This variable has a positive coefficient meaning that this changer has a direct relationship with production so that it can be said that the labor factor gives a positive influence over the goat productivity. The result having positive but not significant influence over the labor variable is caused by the real condition in the research area where the labor used is the family of the goat farmers themselves. Not active enough but with a high number of involvements causes ineffective and inefficiency in conducting the farming activity.

\subsection{Technical Efficiency Analysis of Peranakan Etawah Goat Farming}

Technical efficiency analysis aims to know the highest and the lowest efficiency as well as the average efficiency achieved by the farmer in running Peranakan Etawah goat production in North Samarinda SubDistrict. The level of efficiency achieved by respondents in the research area can be seen in Table 3 .

Based on Table 3, it can be seen that the largest number of respondents ie 9 people are at a level of technical efficiency of more than 0.90. In technical efficiency between 0.80 to 0.90 , there were 4 respondents. Whereas on technical efficiency between 0.70 to 0.80 there was 1 person. The average value of technical efficiency achieved by respondent breeders was 0.92, meaning that most of the Peranakan Etawah goat farmers at North Samarinda sub-district in combining the factors of production have technically efficient (cut-off value efficiency> 0.70 [9].

\subsection{Analysis of Factors Influencing Peranakan Etawah Goat Farming Inefficiency}

Factors put into the model of this research are the number of goat ownership, size of cage, farmer's age, farming experience, and formal education. The analysis result of inefficiency effect can be seen in Table 2 . Interpretation of each source of technical inefficiency is presented below. 


\subsubsection{The number of goat ownership}

The coefficient value of number goat ownership is positive by 0.661 and the $\mathrm{t}$-count value is 2.541 . $\mathrm{t}$-count value is higher than the t-table at a level of 5\% (1.761) as a result, the number of goat ownership has significant influence over the technical inefficiency. This result suggests that the technical efficiency effect in Peranakan Etawah goat production in the study area declined with the increase in labor. This means that number of goat ownership has a negative effect on technical efficiency in Peranakan Etawah goat production in the study area, suggesting that labor is important for achieving effective utilization of inputs in Peranakan Etawah goat production in North Samarinda Sub-District. When the number of goat ownership exceeds the ability of the manpower availability makes the production inefficient. The same is demonstrated from the research results of [16] showing that the number of goats ownership is positive and significant in regard to technical inefficiencies.

\subsubsection{Size of cage}

The coefficient value of size cage is positive by 0.204 and $\mathrm{t}$-count value is 0.718 . $\mathrm{t}$-count value is higher than $\mathrm{t}$ table by $0.718>0.692$. This indicates that the variable has a significant influence over the technical inefficiency with error level by $25 \%$ or trust level by $75 \%$. This means that the changer has an indirect relationship with production so that it can be said that size of cage gives a negative influence over the Peranakan Etawah goat production where can decrease production. The negative influence of size goat cage is caused by the one used by a farmer does not conform to the standard capacity, $\left(0.75 \mathrm{~m}^{2}\right.$ per buckling determined [17]. This result suggest that size of cage is important, every goat needs their required space for proper growing and better production.

\subsubsection{Feed supplement}

The coefficient value of the feed supplement is positive by 0.215 and the $\mathrm{t}$-count value is 0.718 . The $\mathrm{t}$ count value is higher than the table by $0.726>0.692$. This indicates that the variable has a significant influence on the goat productivity with an error level of $25 \%$ or a trust level of $75 \%$. Feed supplement is measured with a dummy, where the farmers who use feed supplement are given a value of 1 , and farmers who do not use feed supplement was given a value of 0 . The results of the research of positive coefficients are 0.215 , meaning that additional feed is a role of goat weight of $0.215 \%$. The respondent farmer who has a value of 1 means using the additional feed, interpreted to affect goat weight by $0.215 \%$ higher. The study revealed that the farmers are faced with the problem of lack of access the supplement feed.

\subsubsection{Age of farmer}

The coefficient value of farmer's age is positive by 0.107 and the t-count value is 0.304 . $t$-count value is smaller than t-table by $0.304<0.692$ so that the factor of farmer's age has a positive but not significant influence over the technical inefficiency with a $25 \%$ error level. This indicates that the older the farmer, the farther the possibility to achieve technical efficiency. This shows that most of the farmers are young and agile to carry out the production activities. This result suggests that age may increase technical efficiency because young farmers who are very energetic and may have learned efficient routines and practices constitute the majority of Peranakan Etawah goat farmers in the study area mers in the study area.

\subsubsection{Farming experience}

The estimation result of Table 2 indicates that farming experience has a negative value and has significant influence over the technical inefficiency with a $10 \%$ error level. Experience variable coefficient by 0.491 with a t-count value higher than t-table by -1.535 > 1.345. This means that the changer has an indirect relationship with production so it can be said that the farming experience gives a positive influence over the Peranakan Etawah goat farming where can increase production.

\subsubsection{Education level}

The coefficient value of farmer's education level factor has a positive sign by 0.228 and t-count by 1.055 higher than t-table that is $1.055>0.692$ so that the factor of the education level of the respondent not only has a positive sign but also has a significant influence on the technical inefficiency with error level by $25 \%$. Formal education is measured based on the educational background posited Peranakan Etawah goat farmer to finish his/her study. The same is demonstrated from the research results of [15] showing that formal education is positive and significant in regard to technical inefficiencies.

\section{CONCLUSION}

The study has shown the distribution of technical efficiency of Peranakan Etawah goat farmers in the North Samarinda Sub-District. Farmer's specific factors like farming experience contributed positively to the technical efficiency level of the goat farmer in the study area. Also, production inputs like the number of bucks, frequency of feed, frequency drug/vitamin, and labor contributed positively to technical efficiency level. Furthermore, $98.5 \%$ of the variations in input use among the Peranakan Etawah goat farmers were due to inefficiency on the part of the farmers rather than random 
variability. More so the distribution of efficiency estimates among the Peranakan Etawah goat farmers has shown a high level of technical efficiency. On average, the technical efficiency of the Peranakan Etawah goat farmers could be increased by $8 \%$, using the current production technology. Although the goat farmers are faced with problems lack of access to the supplement feed. This would lead to increase in productivity, and efficiency gains.

\section{REFERENCES}

[1] M.I. Haris, Soeparno, U. Santoso, Rusman. 2015. Study on the chemical characteristics of meat from goat given ration papaya leaves (Carica papaya L.). The $6^{\text {th }}$ International Seminar on Tropical Animal Production.Integrated Approach in Developing Suistainable Tropical Animal Production. Samarinda. 20-22 Oktober 2015. 709-713.

[2] Direktorat Jenderal Peternakan Dan Kesehatan Hewan. 2019. Kementan Rumuskan Skema Pembiayaan Usaha Pembiakan dan Pembibitan Domba Kambing Berkelanjutan. https:/bit.ly/2TIBgO5.

[3] T.D. Soejana. 2011. Peningkatan Konsumsi Daging Ruminansia Kecil Dalam Rangka Diversifikasi Pangan Daging Mendukung PSDSK 2014. Pusat Penelitian dan Pengembangan Peternakan:Workshop Nasional Diversifikasi Pangan Daging Ruminansia Kecil 2011. (17-26)

[4] R. Aka. 2008. Doe productivity and kid crop of etawah grade does kept under individual ang group housing in Turi Sub-District, Sleman District-DIY province. Mediagro. Vol 4(2):25-31

[5] H. Mayulu, Sunaryo., C.I. Sutrisno, Sumarsono. 2010. Kebijakan pengembangan peternakan sapi potong di Indonesia. Jurnal Litbang Pertanian. Vol.29(1): 34-41.

[6] S.N. Rahmatullah, D. Sudarya, Askalani, N.M.K. Azizi. 2016. Strategi pengembangan ternak sapi dalam mendukung pemenuhan protein hewani di Kalimantan Timur.Jurnal Kebijakan Pembangunan. Vol.11(2):159-170

[7] A. Batubara, N. Saddat, Subandriyo, I. Inounu, B. Tiesnamurti, A. Anggraeni. 2016. Kambing Peranakan Etawah. Badan Penelitian dan Pengembangan Pertanian. https://bit.ly/2IYbbYr. 22 Mei 2018. ISBN: 978-602-344-155-6.

[8] W. Adiyoga. 1999. Beberapa Alternatif Pendekatan Untuk Mengukur Efisiensi atau In-Efisiensi dalam Usahatani. Badan Penelitian dan Pengembangan Pertanian: Informatika Pertanian. Bandung. Vol 8. 487-497. https://bit.ly/2MP1hXk. 8 Juli 2018.
[9] D.P. Darmawan. 2016. Pengukuran Efisiensi Produktif Menggunakan Pendekatan Stochastik Frontier. Hal.1-120. Dalam: Aribawa, D. Pengukuran Efisiensi Produktif Menggunakan Pendekatan Stochastik Frontier. Cetakan Pertama. Elmatera.Yogyakarta. ISBN: 978-602-1222-88-1.

[10] M.E. Suriaatmaja. 2015. Optimalisasi input usaha tani padi (studi kasus Desa Clumprit Kecamatan Pagelaran Kabupaten Malang). Agrifor. Vol.14(2) http://ejurnal.untagsmd.ac.id/index.php/AG/article/view/1428

[11] P.L. Widhiasih. 2014. Peran Kelompoktani terhadap Efisiensi Produksi Kemangi di Desa Ciaruteun Ilir Kecamatan Cibungbulang, Bogor. Tesis. Institut Pertanian Bogor, Bogor. 17 Juli 2019.

[12] S. Aisyah. 2012. Analisis efisiensi penggunaan faktor-faktor produksi pada usaha ternak sapi perah rakyat di Kecamatan Getasan Kabupaten Semarang. Economics Development Analysis Journal. Vol 1(1): $35-41$

[13] Ashari, AA. Yuni, IM. Sukarsa. 2013. Analisis efisiensi produksi usaha peternakan ayam ras pedaging di Kabupaten Tabanan. E-jurnal Ekonomi dan Bisnis. Vol 2(6): 394-408.

[14] I. Indrayani, R. Nurmalina, A. Fariyanti, A. 2012. Analisis efisiensi teknis usaha penggemukan sapi potong di Kabupaten Agam Provinsi Sumatera Barat. Jurnal Peternakan Indonesia. Vol 14(1): 286296.

[15] S. Maemunah, Y.I. Agus. 2017a. Faktor penentu inefisiensi teknis pada usaha ternak kambing Peranakan Etawah (studi kasus di Kelompok Agribisnis As-Salam Kota Tasikmalaya). Mimbar Agribisnis. Vol 3(2): 169-184.

[16] S. Maemunah, D. Sufyadi, I. Hodiyah. 2017 b. Analisis efisiensi teknis usaha ternak kambing Peranakan Etawah. Mimbar Agribisnis. Vol 3(1): 40-52.

[17] Peraturan Menteri Pertanian. 2014. Pedoman Pembibitan Kambing Dan Domba Yang Baik. 1-16. Jakarta. https://bit.ly/2MHVOSj. 4 Juli 2018. 